\title{
A Revision of Lycopodiaceae from Uruguay
}

\author{
Marcelo D. Arana ${ }^{1 *}$, H. Andrés Gonzalez ${ }^{2}$, Mauricio Bonifacino ${ }^{2}$, Carlos A. Brussa ${ }^{3}$ \\ ${ }^{1}$ Orientación Plantas Vasculares, Departamento de Ciencias Naturales, Facultad de Ciencias Exactas, \\ Físico-Químicas y Naturales, Universidad Nacional de Río Cuarto, Ruta 36 km 601, X5804ZAB Río Cuarto, \\ Córdoba, Argentina \\ ${ }^{2}$ Facultad de Agronomía, Universidad de la República, Avda. E. Garzón 780, Montevideo, Uruguay, \\ ${ }^{3}$ Museo y Jardín Botánico de Montevideo "Prof. A. Lombardo", 19 de Abril 1811, Montevideo, Uruguay, \\ *Corresponding Author: Marcelo D. Arana, Orientación Plantas Vasculares, Departamento de \\ Ciencias Naturales, Facultad de Ciencias Exactas, Físico-Químicas y Naturales, Universidad Nacional de \\ Río Cuarto, Ruta 36 km 601, X5804ZAB Río Cuarto, Córdoba, Argentina
}

\begin{abstract}
The Lycopodiaceae is a family of homosporous Lycopsids, presently consisting of 16 genera grouped in three subfamilies, mainly of Neotropical distribution. As part of floristic surveys in Sothern Cone of South America, a revision of Lycopodiaceae in Uruguay is presented. The Lycopodiaceae are represented by eight species, disclosed the first report of Lycopodiella geometra and the confirmation of the presence of Phlegmariurus reflexum in the lycophyte flora of the country, the last one constitutes a novelty of genus level for Uruguayan flora. A dichotomous key, descriptions, maps of distribution and notes on ecology of all taxa of Lycopodiaceae registered for Uruguay are presented and discussed. The populations of Diphasiastrum thyoides, Lycopodiella tupiana,Lycopodium clavatum and Phlegmariurus reflexus in Uruguay represent the austral limit of the distribution of the species.
\end{abstract}

Keywords: Lycopodiaceae, Lycopodiopsida, Neotropics, Taxonomy, Uruguay

\section{INTRODUCTION}

Lycopsids (Lycopodiopsida) are an ancient group with an extensive fossil record, the group includes some of the earliest known land plants and was a major component of the Late Paleozoic vegetation (Wikstrom \& Kenrick, 2001). The group was soon recognized as the product of an early cladogenic event in land plant evolution (Kenrick \& Crane, 1997). Recent phylogenetic analyses support this view and indicate that lycopsids are sister to all remaining vascular plants (Doyle 1998, Pryer et al. 2004). The fossil record provides strong evidence that the three extant lineages (Lycopodiaceae, Selaginellaceae and Isoëtaceae) also originated in the late Palaeozoic (Wikstrom \& Kenrick, 2001).

The Lycopodiaceae is a family of homosporous Lycopsids in which the species exhibit shoot-forms associated with their habitat, sothe generic classification of Lycopodiaceae has been contentious. In the Lycopodiaceae, multiple genera, sections and subfamilies corresponding with the different shootforms, gametophyte and spore types were recognised following multi-character systematic studies on the family (Bruce 1976, Holub 1964, Øllgaard 1975, 1979, 1983, 1987, 1989, 1990, 1992, 1994, 2004, Wagner \& Beitel 1992, Wilce 1972). Early treatments of this family usually included all of the species together in the large and polymorphic genus Lycopodium L. (e.g. de la Sota 1977, Rolleri 1979, 1981, Tryon \& Tryon 1982). One exception was the small and morphologically divergent Australian and New Zealand pygmy-clubmoss Phylloglossum drummondii Kunze which was historically placed in a genus of its own (Kunze 1843) or even in a separate family. Some authors also considered the genera Huperzia Bernh. and Phlegmariurus Holub in the separated family Huperziaceae (Holub 1964, Ching 1981, 1982). Recent molecular studies (e.g. Ji et al., 2008) indicated that Huperziaceae and Phylloglossaceae should be merged in Lycopodiaceae (PPG I, 2016).

Now Lycopodiaceae is subdivided in up to 16 monophyletic genera (Holub 1964, 1975, 1983, 1985, 1991, Wagner \&Beitel 1992, Arana \& Øllgaard 2012, Øllgaard 2012a, 2012b)grouped into three subfamilies (Arana \& Øllgaard 2012, Øllgaard2015, PPG I 2016). The Lycopodiaceae comprises approximately 400 living species globally distributed, but about half of them in the Neotropics. The Lycopodiaceae occupies the widest range of habitats and exhibits a diversity of life forms that include 
vines, small deciduous semi-aquatics, robust scrambling and clump-forming terrestrials and pendent epiphytes, especially in Andean region of South America.

As part of floristic surveys in the Southern Cone of South America, numerous field studies in Uruguay and consultation of herbarium collections worldwide with Uruguayan specimens were carried out. The first specific attempts of taxonomic treatment of Lycopodiaceae in Uruguay were carried out by Legrand \& Lombardo (1958) and Arana \& Øllgaard (2012), but they were conducted as part of major studies. Within checklists, we can highlight the studies of Brussa\&Grela (2005) and Rolleri (2008) but they are out of date. Subsequently a very few publications reported new occurrences of Lycopodiaceae for the country (Gonzalez et al. 2015, 2016). A comprehensive specific taxonomic survey of Lycopodiaceae in Uruguay is still pending. Thus, the goal of the present study is to present a taxonomic revision of Lycopodiaceae occurring in Uruguay including an identification key, morphological descriptions, diagnostic illustrations, distribution maps and ecological remarks of all species.

\section{MAterials AND MethodS}

Uruguay (formerly República Oriental del Uruguay) is a country located in the Southern Hemisphere on the Atlantic seaboard of South America between 53 and 58 west longitude and 30 and 35 south latitude. Uruguay with $176,215 \mathrm{~km}^{2}$ is geographically the second-smallest nation in South America after Suriname. The country is bounded by Argentina to its west and Brazil to its north and east, with the Atlantic Ocean to the south and southeast. Uruguay is part of the South American Platform and its geology consists of aPrecambrian basement cropping out in the southern part, and Paleozoic to Mesozoic sediments and Mesozoic basaltic flows in the northern region, the latter being part of the Paraná Basin (Panario et al., 2014). Most of Uruguay is a rolling plain that represents a transition from the Argentine pampas to the hilly uplands of southern Brazil, the highest point, the Cerro Catedral (514 m above sea level), is located in the southeast of the country in the Cuchilla Grande mountain range. The country itself has flat plains on its eastern, southern, and western edges. The narrow Atlantic coastal plain is sandy and marshy, occasionally broken by shallow lagoons. The littorals of the Río de la Plata and the Río Uruguay are somewhat broader and merge more gradually into the hilly interior. Located entirely within the temperate zone, Uruguay has a humid subtropical climate, seasonal variations are pronounced, but extremes in temperature are rare, with an annual rainfall of $1200 \mathrm{~mm} \mathrm{yr}^{-1}$ and a mean temperature of $18{ }^{\circ} \mathrm{C}$ (Panario et al. 2014). Biogeographically, Uruguay is entirely merged into Pampean province of the Neotropical region (Morrone, 2014).

This study is based on the critical review of relevant literature and morphological data that were gathered from living specimens during fieldwork and from specimens on loan and/or electronic images from the following herbaria: BA, CORD, CTES, G, JUA, K, LIL, LP, MCNS, MERL, MVBJ, MVFA, MVM,P, RB, RCVC, RIOC, SI and SRFA. We also conducted field trips to different regions of the country and studied the original description and type specimens of all names cited for Uruguay, the relevant information referred to the distribution and habitat features. Sampling was done in an unsystematic way in order to go through all of the vegetation types in Uruguay. Information regarding the habitat and habit of collected plants was recorded. The plants were collected and processed according to standard techniques for lycophytes (Bridson \& Forman 1998) and the voucher specimens are kept in RCVC and MVFA herbaria. All taxa are arranged by alphabetical order and Author names of taxa were abbreviated according to the International Plant Names Index (IPNI) (Brummit \& Powell 1992).Morphological descriptions were based on Arana \& Øllgaard (2012) and Arana et al. (2012) and the descriptions of the spores are based mainly in Ramos Giacosa et al. (2016).Mapping of geographic distributions employed Corel DRAW Graphics Suite X6 software. Geographical coordinates are given for all collected specimens. Coordinates not available on the original labels of ancient material were assigned to the middle point of the department of occurrence or looking for the locality in Google Earth.

\section{RESULTS AND DISCUSSION}

The family Lycopodiaceae is represented in Uruguay by eight taxa representing six genera grouped in the three subfamilies: Huperzioideae (Phlegmariurus),Lycopodioideae (Diphasiastrum, Lycopodium) and Lycopodielloideae (Lycopodiella, Palhinhaea, Pseudolycopodiella); Lycopodiella geometra is a new species for Uruguayan flora, and the species Phlegmariurus reflexus is confirmed for the flora, the last one is a novelty of genus level. The best represented genus is Lycopodiella, with three species, 
the other genera are represented by one species each.Despite the Uruguayan biodiversity of Lycopodiaceae, the populations of Diphasiastrum thyoides, Lycopodiella tupiana,Lycopodium clavatum and Phlegmariurus reflexus in Uruguay represent the austral limit of the distribution of the species, which is important in floristics, biogeographical and conservation viewpoints.

Most species occur in the northeastern part of the country, especially in the northeastern highlands (montane grasslands), andin the northernmost part of the coastal lowlands around the southern limit of the Atlantic rain forest.

\section{Taxonomic treatment}

Lycopodiaceae Mirbel, in Lamarck \& Mirbel, Hist. Nat. Veg. 4: 293 (1802). Type:-Lycopodium L. =Huperziaceae Rothm., Feddes Repert. 66: 236 (1962). Type:-Huperzia Bernh. =Phylloglossaceae Kunze, Bot. Zeitung (Berlin) 1: 722. 1843. Type:-Phylloglossum Kunze. =Urostachyaceae Rothm., Feddes Repert. 54: 58 (1944), nom. illeg., based on Urostachys Herter, nom. illeg.

Terrestrial or epiphytic, erect to pendulous herbs. Stems dichotomously branching, rarely with lateral branching, protostelic, with xylem arranged radially or in parallel bands. Lycophylls simple, with one simple vein, arranged in low alternating spirals or irregular whorls, or seemingly decussate, homophyllous or heterophyllous, isophyllous or anisophyllous. Sporophylls like the foliage leaves, or modified, sometimes specialized and aggregated intodistinct strobili. Sporangia solitary, in lycophyll axils or on the adaxial side of the sporophyll base,homosporous, unilocular, reniform to subglobular, short-stalked, dehiscing by transverse slits that divide each sporangium into two valves. Spores subglobose to tetrahedral, with a trilete scar, without chlorophyll. Gametophytes monoecious, tuberous, subterranean andholosaprophytic, or surface-living, green, and hemisaprophytic.

\section{Key to the species of Lycopodiaceae in Uruguay}

1. Isotomous shoots. Strobili absent. Phlegmariurus reflexus

1. Anisotomous shoots. Strobili always present........................................

2. Inclinate isotomous branching. Strobili erect, sessile or pedunculate, borne on branchlet systems that arise in a dorsolateral position on the main stem. .3

3. Leafy branchlet isophyllous Lycopodium clavatum

3. Leafy branchlets anisophyllous Diphasiastrum thyoides

2. Laterally spreading horizontal flabellate sterile branches; Strobili pendulous and sessile, or strobili erect and terminating simple (or to 2-forked) branches that arise dorsally on the creeping or looping stems. ...4

4. Strobili pendulous or nodding, terminating amply branched branchlet systems that are borne on an erect, tree-like main branch Palhinhaea cernua

4. Strobili erect, terminating simple or forked erect branches that arise dorsally on the creeping stems. .5

5. Sporophylls with entire to minutely denticulate-fimbriate margins, sporangia nearly isovalvate. ...Pseudolycopodiella meridionalis

5Sporophylls with few to several, prominent teeth, sporangia anisovalvate................................................. Lycopodiella

6. Main axis of the plant arched, not appressed to the substrate, lateral axis 24 isotomous forked L. geometra

6. Main axis of the plant not arched, appressed to the substrate, lateral axis simple or anisotomous 7

7. Strobili with sporophylls patent to loosely appressed, 5-9 mm, not caudate. Lycophylls of main stems with ciliate to dentate margins, rare entire L. longipes 
7. Strobili with sporophylls appressed, 3.5-6 mm, caudate. Lycophylls of main stems with entire to denticulate margins

L. tupiana

1. Diphasiastrum Holub, Preslia 47: 104. 1975. Type:-Diphasiastrum complanatum (L.) Holub (=Lycopodium complanatum L.).

=Lycopodium subg. Complanatostachys Herter, Bot. Jahrb. Syst. 43: Beibl. 98: 29. 1909

(p.p.).

=Lycopodium subgen. Thujophyllium Börner, Fl. Deutsche Volk. 110. 1912.

=Lycopodium sect. Complanata Victorin, Contr. Lab. Bot. Univ. Montreal 3: 34, 89. 1925.

=Diphasium Rothm. ser. Complanata Rothm., Feddes Repert. 54: 64. 1944. Type:Lycopodiumcomplanatum $\mathrm{L}$.

Sporophytes with subterranean, or creeping to subscandent main stems; branchletsdorsiventral, anisophyllous with decussate, trimorphic lycophylls, one dorsal and one ventral rank of narrow lycophylls, and two lateral ranks of broad laterally compressed lycophylls; branchlet leaves herbaceous throughout; strobili pedunculate; sporophylls subpeltate; sporangial epidermal cells with evenly sinuate side walls; spores reticulate on all faces; gametophytes dauciform. $X=23$.

This description applies to the Southamerican material only. Some species (especially in North America and East Asia) have radial, isophyllous branchlets.

Diphasiastrum occurs in the Northern temperate, arctic and alpine regions, mountains in the tropics, absent from Australia, presenting approximately 23 species. Two species in South America with one of them occurring in Uruguay (Gonzalez et al. 2015).

1a. Diphasiastrum thyoides (Willd.) Holub, Preslia 47: 108. 1975. Lycopodium thyoides Willd., Sp. Pl.: 18. 1810. Stachygynandrum thyoides (Willd.) C. Presl; Abh. Königl. Böhm. Ges. Wiss. 3: 583. 1845.Lycopodium complanatum L. var. thyoides (Willd.) Christ, in Schwacke, Pl. Nov. Min. 42.1900. Lycopodium complanatum L. var. thyoides(Willd.) Hieron., in Engl. Bot. Jahrb. 34. 576. 1905. Type:-VENEZUELA. Distr. Federal: "Crescit in monte Silla de Caracas", Humboldt s.n. (holotype B!ID B-Willd. 19352! Isotype P! ID P00669220).

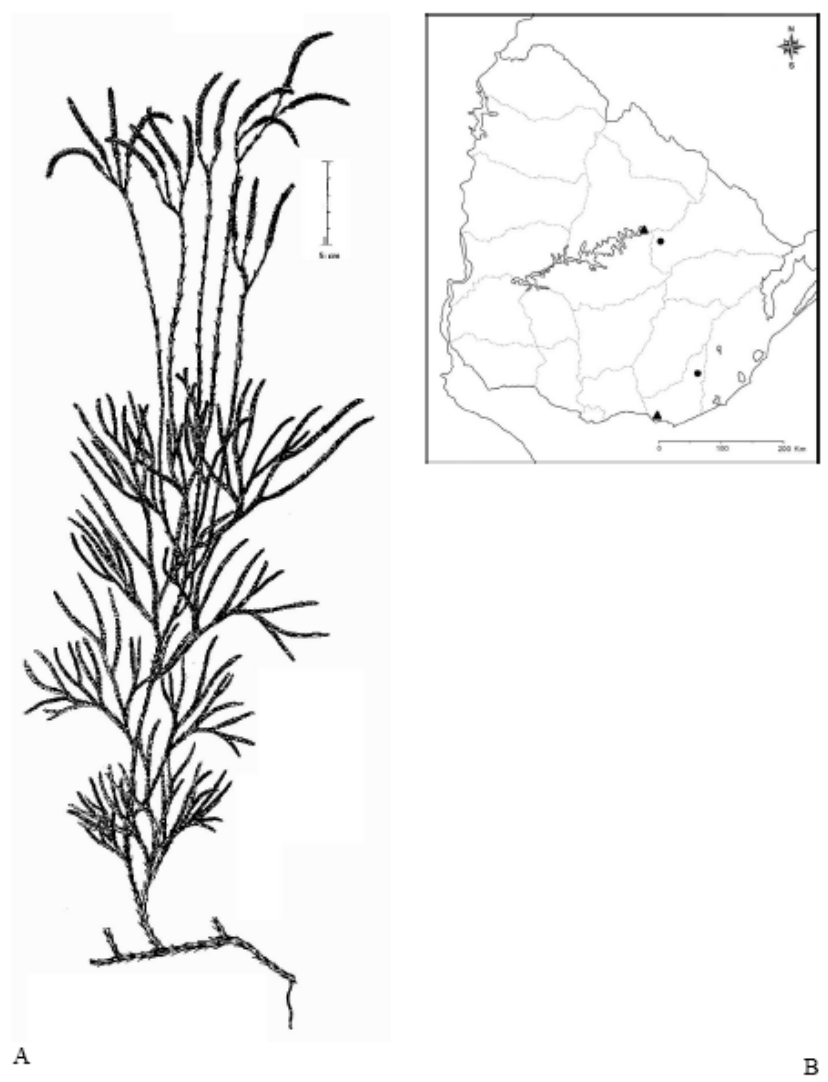

Figure 1. A. Diphasiastrum thyoides habit. B. Distribution of Diphasiastrum thyoides (circles) and Lycopodium clavatum (triangles) 
Lycopodium comptonioides Desv., Mem. Soc. Linn. Paris 6: 185, 1827. (excl. synonyms).Type:BRAZIL. "Locis montosis Brasiliæ", Herbier de A. N. Desvaux, donnée par Mme Vve Lavallée, 1896. With Desvaux's label and annotation (holotype P! ID P00559221).

Plants with creeping, trailing to scandent aerial parts. Main stems usually aboveground, terete. Main stem lycophylls relatively distant, borne in irregular spirals, or subverticillate, subulate, appressed to ascending. Aerial shoots arising from the rhizomes in a dorsolateral position, ascending to erect, up to $50 \mathrm{~cm}$ tall. Main upright axis terete to somewhat flattened, bearing lateral, flattened, fan-shaped branchlet systems. Ultimate branchlets flattened, dorsiventral, anisophyllous, with trimorphic, decussate lycophylls in 4 ranks. Distal, median branchlet lycophylls with pointed, subulate to acicular, appressed, 1-2 mm long, free blades, and a conspicuous, prominently decurrent base. Lateral branchlet lycophylls bilaterally compressed, long-decurrent, the free blades 1-3 mm long, appressed to spreading, acuminate to long-pointed. Ventral lycophylls inconspicuous, acicular, without decurrent base, 1-2 mm long. Strobili pedunculate. Peduncles terminating main erect axis or major axes of distal branchlet systems, up to $25 \mathrm{~cm}$ long, terete, with rather distant, subulate, appressed lycophylls, each bearing 4-9 pedicellate strobili. Strobili $1.5-5 \mathrm{~cm}$ long. Sporophylls usually borne in alternating whorls of 3, forming 6 longitudinal ranks, subpeltate, with a basiscopic, median wing on the stalk, with broadly deltate-ovate, long-cuspidate, ca. $2-3 \mathrm{~mm}$ long, $1.5-2 \mathrm{~mm}$ wide exterior face, with erose-laciniate to almost entire, broadly membranous margins. Sporangia $1.5-2 \mathrm{~mm}$ diam. Spores densely reticulate on all faces.

Distribution and habitat: Throughout moist mountainous regions of Tropical America, south to central Argentina and southeast Uruguay, this point represents the southernmost limit of the distribution of the species. The species in Uruguay occurs in fields andstony fields with high solar radiation.

Selected Material:URUGUAY. Cerro Largo: Arévalo, cerca del cementerio, en paredón al sol, poco

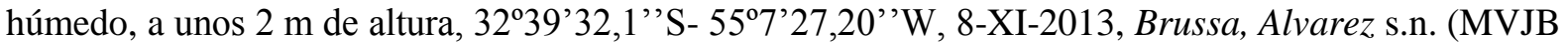

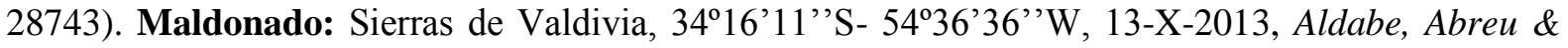
González 1039 (MVFA).

2. Lycopodiella Holub, Preslia 36: 20, 22. 1964. Type:-Lycopodiella inundata (L.) Holub (=Lycopodium inundatum L.).

Plants creeping on wet ground. Roots emerging immediately on underside of stems. Horizontal stems on substrate surface, supine or arching. Upright shoots forming very leafy peduncles scattered along horizontal stems, unbranched. Strobili solitary, fully differentiated from peduncle or peduncle not differentiated, tip blunt to \pm acute; peduncle leafy, lycophylls not in distinct ranks, not imbricate, usually monomorphic, linear-lanceolate, margins commonly with a few teeth; sporophylls generally longer than peduncle lycophylls. Sporangia nearly globose. Spores rugulate, sides at equator convex, angles acute. Gametophytes photosynthetic, on substrate surface, pincushion-shaped. $\mathrm{x}=78$.

About 10 species, mainly in north temperate region and tropical America, three species in Uruguay:

2a. Lycopodiella geometraB. Øllg. \& P. G. Windisch, Bradea 5(1): 30, f. 4A. 1987. Type:- Brazil. Minas Gerais: Mun. Santansa do Riacho, estrada de Lagoa Santa a Conceiçao do Mato Dentro, km 132 (antigo), Serra do Cipó, campo rupestre, entre gramíneas, alt. ca. 1250 m, 2-II-1987, J. Prado et al. 80 (holotype HB!, isotypes AAU!, SP!, SPF!).

Horizontal shoot system arching to looping, rooted with long intervals at soil contact, bearing laterally arising, erect, up to several times subequally dichotomous branchlet systems, and dorsally arising, stiffly erect, simple or up to 3 times subequally dichotomous, at least up to $50 \mathrm{~cm}$ tall strobiliferous branches. Main branch of horizontal shoot system up to at least $70 \mathrm{~cm}$ long, covered by ascending to loosely appressed lycophylls, inundated stem portions often swollen. Main branch lycophylls usually flat, subulate, $5-8 \mathrm{~mm}$ long, ca $0.8-1 \mathrm{~mm}$ broad at the base, with coarse, spreading to hooked marginal teeth. Laterally arising erect branchlet systems at least up to $25 \mathrm{~cm}$ high, up to at least 4 times dichotomous. Branchlet lycophylls ascending, arcuate-ascending to arcuate-appressed, densely crowded, concealing the stem, subulate, usually abaxially convex, (2.5-) 4-6 mm long, $0.5-0.8$ (-1) mm broad, with few (or some without) to many spreading teeth, often with a slightly thickened, pale, smooth apex. Strobiliferous branches with uniformly appressed lycophylls, borne in irregular, alternating low spirals or whorls of 8-10, forming 16-20 indistinct longitudinal ranks, essentially conform with those of horizontal main branch. Strobili up to $18 \mathrm{~cm}$ long, $8-20 \mathrm{~mm}$ in diam. 
Sporophylls borne in altenating whorls of $8-10$, forming 16-20 indistinct longitudinal ranks, subpeltate, with narrow transverse and basiscopic wings on the stalk, linear-lanceolate to lanceolate, with coarse, spreading to hooked teeth on the margin, (4-) 5-10 mm long, 1-1.5 (-2) $\mathrm{mm}$ broad at the base. Sporangia axillary, subglobular, strongly anisovalvate, almost completely concealed by sporophyll bases, ca $1 \mathrm{~mm}$ broad.
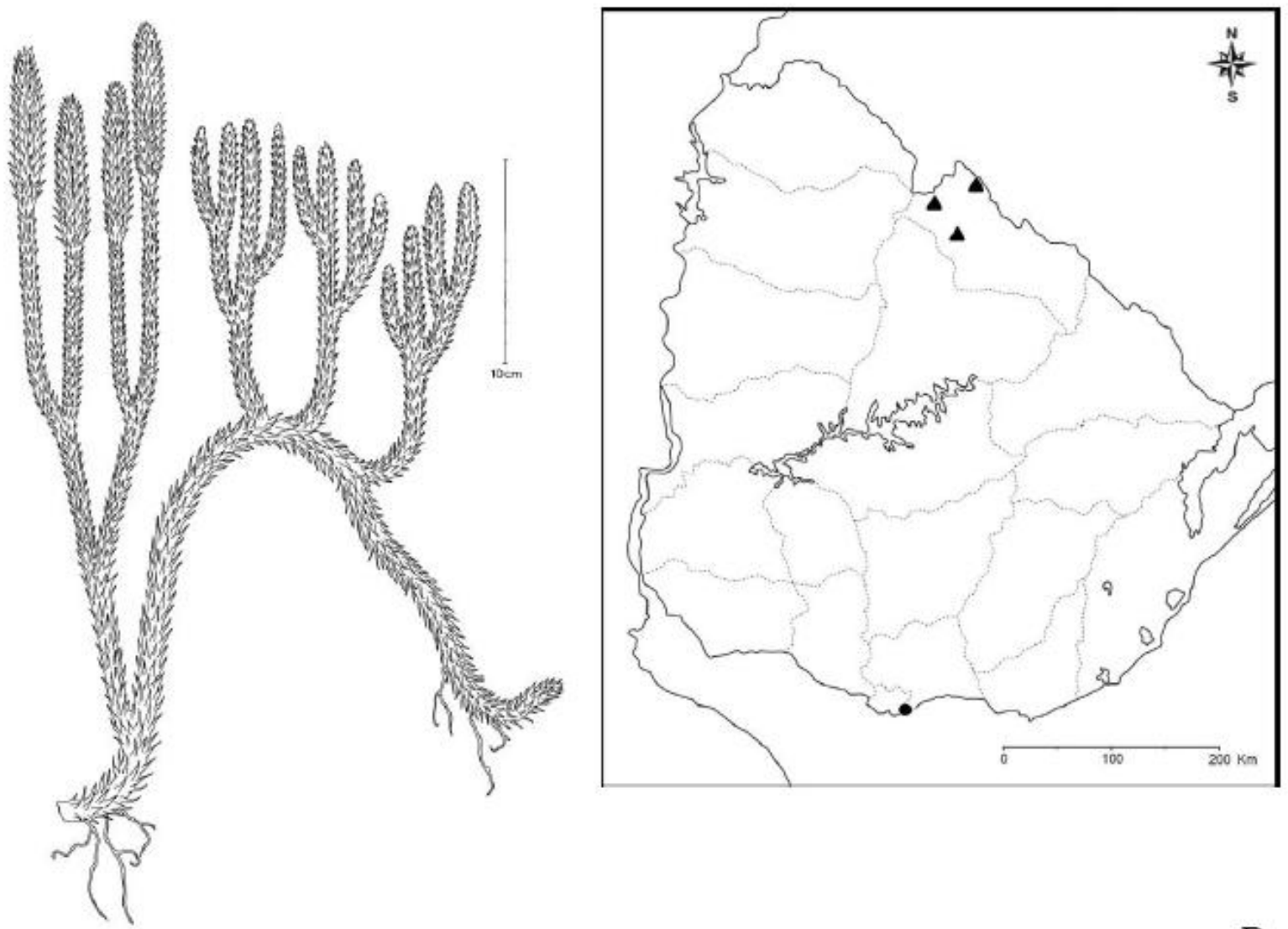

A

Figure 2. A. Lycopodiella geometra habit. B. Distribution of Lycopodiella geometra (triangles) and Lycopodiella longipes (circles)

Distribution and habitat: Planalto of Brazil to Paraguay, Argentina (Corrientes) and Uruguay, in terrestrial, wet or humid, open places in campo vegetation, alt. 100-1300 m.

Selected Material:URUGUAY. Rivera: en campo areno-húmedo, ruta 5 al norte de Tranqueras, 6-I1960, Rosengurtt B-8038 (MVFA); Establecimiento Batoví, Arroyo Batoví, zona de reserva, bañado

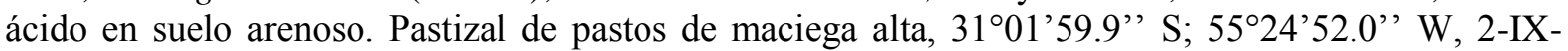
2005, Brussa, C., Grela, I., Escudero, R. \& Alvarez, M. s.n. (MVJB 23204); Establecimiento La Serena, Paso de Gaire, en bañado ácido muy amplio, entre pastos, $31^{\circ} 24^{\prime} 15.8^{\prime}$ S; 55 $34^{\circ} 21.4^{\prime \prime}$ ' W, 5 II-2016, Brussa, C., Brussa, P. \& Álvarez, M. s.n. (MVJB 29568)

2b. Lycopodiella longipes(Hook. \& Grev.) Holub, Folia Geobot. Phytotax. 26: 93. 1991. Lycopodium longipes Hook. \& Grev., en Hooker's Bot. Misc. 2: 372. 1831. Lycopodium alopecuroidesvar. integerrimum Spring, Nouv. Mém. Acad. Roy. Sci. Bruxelles 15: 75. 1842. Lycopodiella alopecuroides var. integerrima (Spring) B. Øllg. \& P. G. Windisch, Bradea 5: 29. 1987. Type:BRAZIL. "Insula St-Catharinae", J. Macrae s.n. (holotype E!; isotype K!).

Horizontal shoots appressed to the ground, firmly rooted with short intervals, bearing stiffly erect, dorsally arising,simple or rarely once forked, at least up to $45 \mathrm{~cm}$ tall, strobiliferous branches. Horizontal shoots at least up to $50 \mathrm{~cm}$ long, unequally branched in the horizontal plane, densely covered on all sides by almost uniform, somewhat upwardly secund, or spreading to perpendicular lycophylls. Lycophylls of horizontal shoots narrowly lanceolate or subulate to linear, flat, with smooth to denticulate or long-ciliate margins, soft, light green, 5-7 (-8) $\mathrm{mm}$ long, $0.5-1(-1.2)$ $\mathrm{mm}$ broad at base. Ventral lycophylls of horizontal shoots conform to only half as broad as lateral and 
dorsal leaves. Erect peduncular branches with lycophylls radially arranged, borne in alternating whorls of 6-10, ca 1.5-3 mm apart, forming 12-20 indistinct longitudinal ranks, essentially like lycophylls of horizontal shoots, sometimes slightly narrower or with more dentate-ciliate margins, usually ascending to closely appressed. Strobili at least up to $16 \mathrm{~cm}$ long, $8-15 \mathrm{~mm}$ in diam. Sporophylls arranged as peduncle lycophylls, linear-lanceolate to broadly lanceolate from a subpeltate base, not coalescent at base, with few to many, coarse, spreading to hooked teeth on margins, 5-7 (-9) $\mathrm{mm}$ long, $1-1.5(-2) \mathrm{mm}$ broad at base. Sporangia axillary, subglobular, strongly anisovalvate, ca. $1 \mathrm{~mm}$ in diam., almost completely concealed by sporophyll bases. Spores rugate, with a distinct equatorial rim.

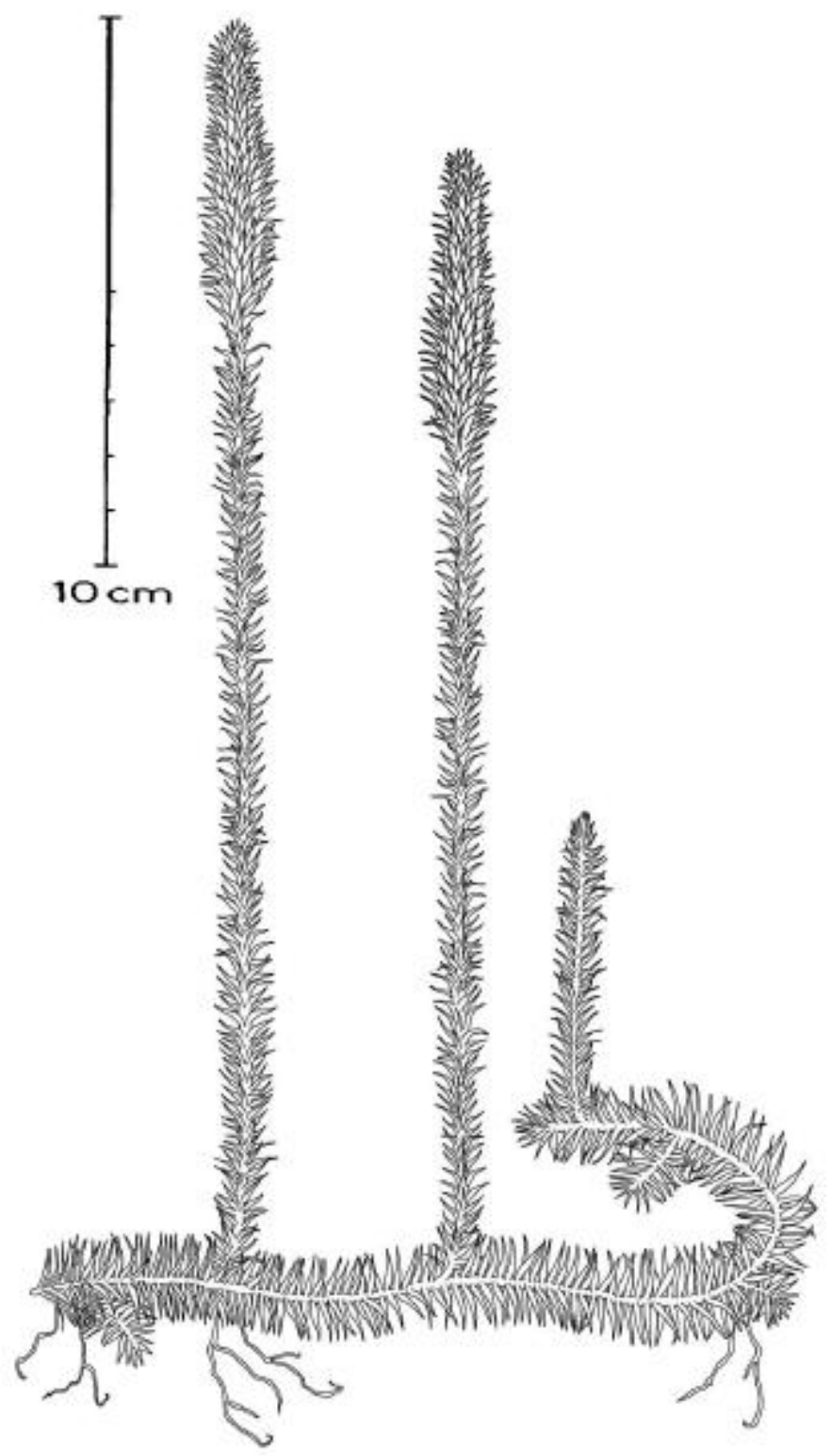

Figure 3. Lycopodiella longipes habit.

Distribution and habitat: Tropical America in Peru, Brazil, Argentina and Uruguay in open, moist localities on sandy and clayey soil, banks of rivers and roads, brejos, wet grassland, from sea level to $2300 \mathrm{~m}$.

Selected Material: URUGUAY. Montevideo. Carrasco, en lugar pantanoso, III-1913, Berro s.n. (MFVA); litoral platense, IV- 1926, Herter 325 (SI).

2c. Lycopodiella tupiana(B. Øllg. \& P.G. Windisch) B. Øllg., Rodriguésia 63: 480. 2012. Lycopodiella alopecuroides (L.) Cranfill var. tupiana B. Øllg. \& P.G. Windisch, Bradea 5: 30, f. 4B. 1987. Type:-BRAZIL. Estado de São Paulo: Peruibe (litoral Sul do Estado) margen da rod. Pe. Manoel da Nobrega, entre Itanhaem e Peruibe, km 120, no solo arenoso, juntamente con $L$. carolinianum, B. Siegel 6 (holotipo HB!). 

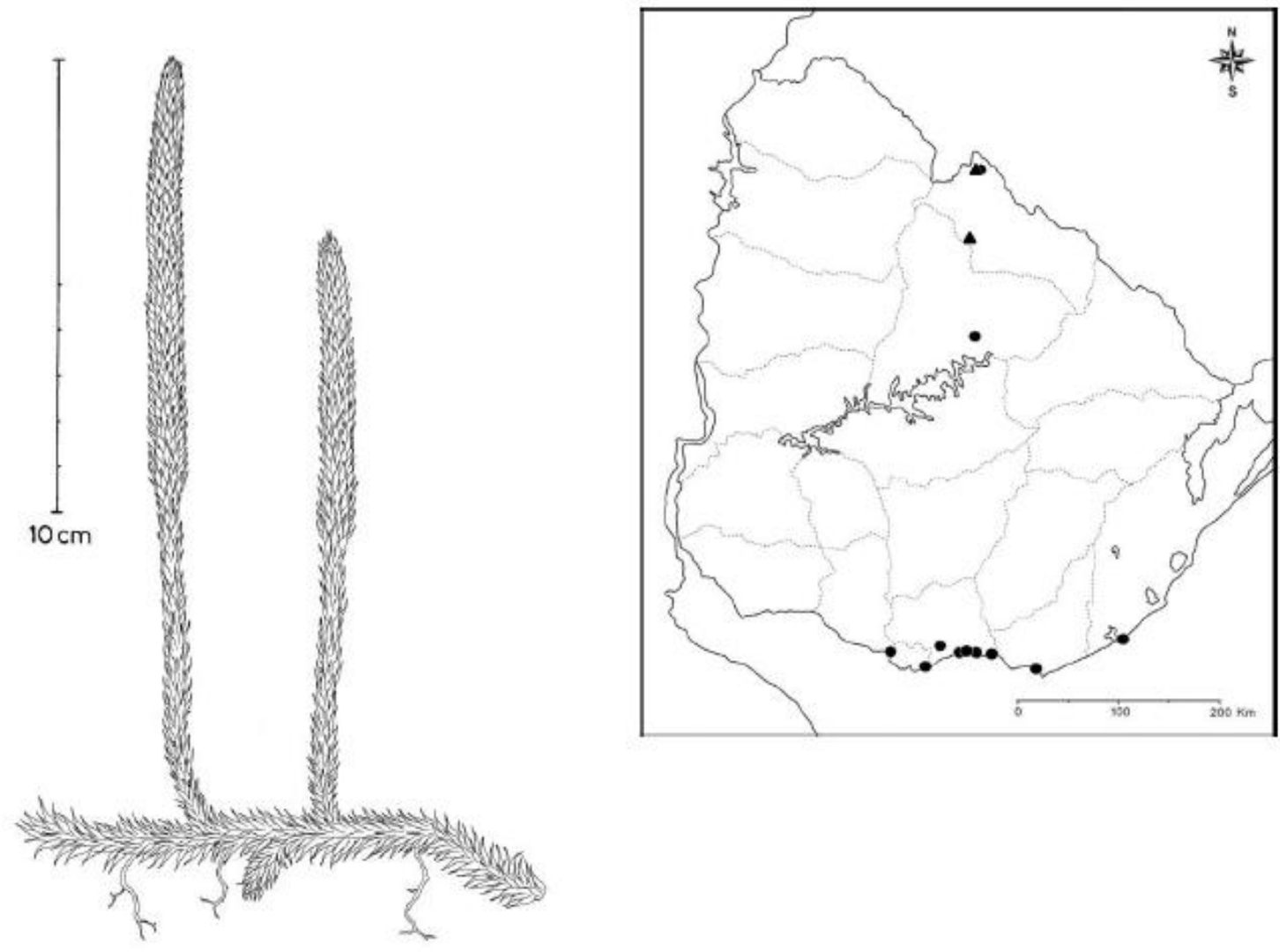

A

Figure 4. A. Lycopodiella tupiana habit. B. Distribution of Lycopodiella tupiana (circles) and Phlegmariurus reflexus var. minus (triangles)

Horizontal shoots appressed to the ground, firmly rooted with short intervals, bearing stiffly erect, dorsally arising, simple at least up to $35 \mathrm{~cm}$ tall, strobiliferous branches. Horizontal shoots at least up to $50 \mathrm{~cm}$ long, unequally branched in the horizontal plane, densely covered on all sides by almost uniform, spreading to perpendicular lycophylls. Lycophylls of horizontal shoots narrowly linear lanceolate or ovate lanceolate, flat, with entire or almost entire margins, soft, light green, 4-6 mm long, 0,8-1(1,5) $\mathrm{mm}$ broad at base. Erect peduncular branches with lycophylls sub verticillate arranged, borne in alternating whorls of $6-10$, ca $1.5-3 \mathrm{~mm}$ apart, forming $12-20$ indistinct longitudinal ranks, essentially like lycophylls of horizontal shoots, sometimes slightly narrower, usually ascending to closely appressed. Strobili at least up to 8-10 cm long, 8-10 $\mathrm{mm}$ in diam. Sporophylls arranged as peduncle lycophylls, lanceolate to broadly lanceolate to ovate from a subpeltate base, not coalescent at base, with few minuscule teeth on margins, $5-7 \mathrm{~mm}$ long, $1-1.5$ $\mathrm{mm}$ broad at base, caudate. Sporangia axillary, subglobular, strongly anisovalvate, ca. $1 \mathrm{~mm}$ in diam., completely concealed by sporophyll bases. Spores rugate, with a distinct equatorial rim.

Distribution and hábitat: from Southeast Brazil to Uruguay, where is relatively common in wetlands or highly humid places, from sea level to $150 \mathrm{~m}$.

Selcted material: URUGUAY. Canelones: Atlántida, 21-II-1922, Osten 16614 (MHNH 1435); Atlántida, XII-1925, Lombardo, A. 1618 (MVJB); Atlántida, XII-1926, Lombardo, A. 5938 (MVJB);La Floresta, 4-IV-1931, Osten 22206 (MNHN 1504); La Floresta, XII-1932, Lombardo, A. 1226 (MVJB); La Floresta, XII-1933, Lombardo, A. 1260 (MVJB); La Floresta, I-1937, Lombardo, A. 1971 (MVJB); Bañados de Pando, I-1944, Lombardo, A. 4988 (MVJB);Las Toscas, en terrenos algo arenosos sombríos, 10-II-1946, Osorio 939 (MNHN 13397); Bañados de Pando, II-1947, Lombardo, A. 4649 (MVJB); Balneario Araminda, 3-IV-1969, Rosengurtt №11087 (MVFA); Balneario Santa Ana, en bañado ácido, junto a playa, 3-IV-1999, Bonifacino \& Beyhaut s.n. (MVFA 28858); Miramar, Bajada 3, zona arenosa inundable, 26-IX-2004, Callero, C. 23 (MVJB 23298).Colonia. Riachuelo, terreno húmedo entre los médanos, IV-1935, Cabrera 3323 (LP); misma localidad, dunas húmedas, 23-III-1937, Cabrera 4009 (LP); misma localidad, Arechavaleta 2057 (P). Maldonado: dunas, 19-I-1900, Osten 3902 (MNHN 1434); Dünen, 8-IV-1925, Herter s.n.; Osten 
17754 (MNHN 1436).Montevideo:Carrasco, en bañados, s.f. Arechavaleta s.n. (MNHN 4161); in uliginosis, III-1874, Gibert 1190 (MNHN 4159); en terreno húmedo, cerca de los bañados, XI-1875, Arechavaleta 471 (MNHN 2057); Carrasco, en bañados, V-1879, Arechavaleta s.n. (MNHN 4160); Carrasco, locis udis in dunis, 20-XI-1910, Osten 5339 (MNHN 1433); Carrasco, locis udis in dunis, 22-XII-1912, Osten 5339 A (MNHN 1432); Carrasco, humid, soli exp., aren, 0-10 M.s.m, lit. Platens, IV-1926, Herter 325 (MNHN 1445); Carrasco, en arenas, 9-IV-1935, Legrand 538 (MNHN 1431); Jardín Botánico, 2-IV-1987, Nicoli, N. s.n. (MVJB 24500);Rivera: Ruta 5, km 490-500 y Arroyo Curticeiras, 11-III-1994, Izaguirre, Brescia \& Marchi s.n. (MVFA 23209). Rocha: Balneario La Paloma, en arena húmeda, 18-I-1965, Brescia \& Marchesi s.n. (MVFA 3972). San José: Barra del Santa Lucía, XII-1925, Lombardo, A. 1670 (MVJB); Barra del Río Santa Lucía, lugar arenoso, graminoso y húmedo, III-1926, Marchesi, E., Lombardo, A. 1199 (MVJB). Tacuarembó: Rincón de Zamora, nacientes de Arroyo Clara, pared barrancosa muy húmeda, sobre cañada, 25-II-1978, Ferrés s.n. (MVFA 15073).

\section{Lycopodium L., Sp. Pl. 2: 1100. 1753. Type:-Lycopodium clavatum L.}

Plants mainly trailing on ground. Roots emerging from point of origin on underside of main stems. Horizontal stems on substrate surface or subterranean, long-creeping. Upright shoots scattered along horizontal stem, round or flat in cross section, unbranched or with 1--4 lateral branchlets. Lycophylls not imbricate, linear to linear-lanceolate; leaves on horizontal stems scattered, appressed, membranous; lycophylls on lateral branchlets mostly 6-ranked or more, monomorphic with few exceptions, appressed, ascending to spreading, margins entire to dentate. Gemmiferous branchlets and gemmae absent. Strobili single and sessile or multiple and pedunculate, apex blunt to acute; peduncle, when present, conspicuously leafy; sporophylls extremely reduced, much shorter than peduncle or stem leaves. Sporangia reniform. Spores reticulate, sides at equator convex, angles acute. Gametophytes nonphotosynthetic, mycorrhizal, subterranean, flat and irregularly button-shaped, with ring meristem around circumference. $\mathrm{x}=34$.

Lycopodium is a genus with around 25 species ofmainly temperate and subarctic distribution. In Uruguay is represented by one species:

3a. Lycopodium clavatum L. subsp.clavatum, Sp. Pl. 1101. 1753. Type:-Herb. Burser XX: 49 (UPS), Lectotype designated by Jonsell \& Jarvis, Reg. Veg. 127: 63. 1993.

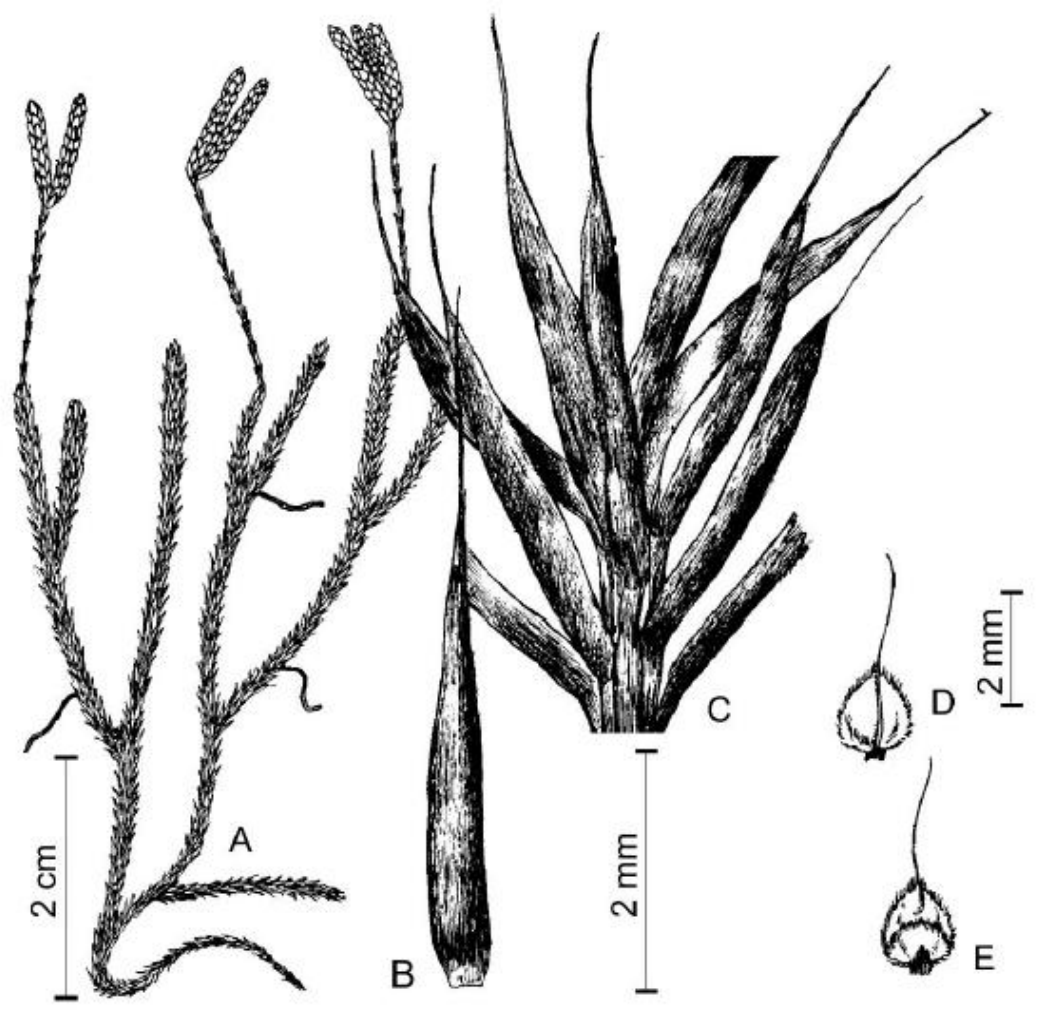

Figure 5. Lycopodium clavatum subsp. clavatum. A habit. B. lycophyll (trophophyll). C. segment of aereal stem. D \& E. Sporophylls. 
Rhizomes creeping, trailing, or hanging overbanks, usually aboveground, rooting with long intervals. Aerial branches ascending to stiffly erect, to atleast $50 \mathrm{~cm}$ tall, repeatedly unequally branched, with strongly diverging to almost parallel branchlets. Ultimate branchlets radial. Lycophylls of mainaxes and branchlets essentially similar, borne in low alternating spirals orwhorls of 6-8(-10), forming 12 16(-20) indistinct longitudinal ranks, patent to ascending or imbricate, linear-acicular, 6-8(-14) mm long, $0.5-0.8 \mathrm{~mm}$ wide at the base, terminating in a long hair ormembranousapex, with smooth to sparsely denticulate margins. Strobili short- to long-pedunculate. Peduncles terminating main axes of branchlet systems, erect, to $30 \mathrm{~cm}$ tall, simple or branched and bearing upto 6 pedicellate strobili. Peduncle leaves distant, appressed, reduced in length, partially membranous. Strobili $1.5-6(-8) \mathrm{cm}$ long, ca. 4-6 mm diam., simple, or sometimes forked. Sporophylls borne in alternating whorlsof (4)5-6, forming (8-)10-12 longitudinal ranks, subpeltate, with a median, basiscopic, membranouswing on the stalk, with triangular-ovate to rhombicovate, acuminate exterior face, 3-5(-12) mm long, ca. 1.4-2 mm wide, with usually broadly scarious, dentate to erose-laciniate margins, and hair like apex. Sporangia 1.3-1.6 mm wide. Spores reticulate on all faces.

Distribution and habitat: almost worldwide but absent in Australia. In America from Canada to Argentina and Uruguay Gonzalez et al., 2016), where is found in rocky slopes of road banks; 0--1300 $\mathrm{m}$.

Note: Lycopodium clavatum in Uruguay is represented by the subspecies clavatum. The subspecies $L$. clavatum subsp. Contiguum (Klotzch) B. Øllg. is found only in places between 2600 to $3800 \mathrm{~m}$ above sea level in Costa Rica, Panama and in Andean regions from Venezuela to Bolivia.

Selected Material: URUGUAY. Depto. Durazno: kilómetro 328de la Ruta Nacional 6, entre las localidades deCuchilla de Ramírez y Los Feos, 32²7'8' S-55²6'44' 'W, 25-XI-2015, González \& Busquetss.n. (MVJB 29707). Depto. Maldonado: Cerro Pande Azúcar, en vertiente del cerro, ladera

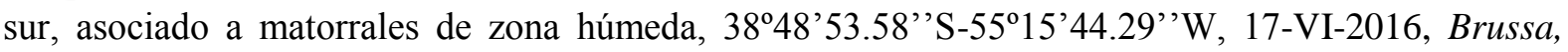
Muñoz, Díaz\& Gago s.n. (MVJB 29735).

4. Palhinhaea Vasconcellos \& Franco, Bol. Soc. Brot. ser. 2, 41: 24. 1967. Type:- Palhinhaea cernua (L.) Vasc. \& Franco (= Lycopodium cernuum L.).

Plants on substrate surface, resembling small, many-branched tree. Roots emerging immediately on underside of stems. Horizontal stems branching, stolonlike, rooting where they touch ground. Upright shoots usually 1 to each arch of horizontal stems, to $3.5 \mathrm{~mm}$ diam., unequally, dichotomously branched with well-differentiated lateral branchlets much branched. Lycophylls not in distinct ranks, not imbricate, monomorphic, generally ascending, linear-needlelike, margin entire. Gemmiferous branchlets and gemmae absent. Strobili solitary, sessile, nodding to pendent, tip blunt; sporophylls smaller than vegetative lycophylls. Sporangia nearly globose. Spore surface rugulate; sides convex at equator. Gametophytes photosynthetic, on substrate surface, pincushion-shaped; ring meristem absent.

Palhinhaea is a very common genus in Lycopodiaceae worldwide, with 15-20 species mainly pantropical and subtropical, in Uruguay is represented by one species:

4a. Palhinhaea cernua(L.) Vasc. \& Franco, Bol. Soc. Broter. 2, 41: 25. 1967. Lycopodium cernuum L., Sp. Pl. 2: 1103, 1753. Lycopodiella cernua (L.) Pic. Serm., Webbia 23(1): 166. 1968. Type:"Habitat in Indiis", en Herb. LINN 1257.13 (lectotype designated by G. R. Proctor, Ferns of Jamaica: 26. 1985, based in an annotation by Stearn in LINN!).

Roots clustered at soil contacts of horizontal stem. Horizontal stems with lycophylls remote, linearneedlelike, recurved at base, upcurved at apex, 2.9--3.1 $\mathrm{mm}$ long, 0.1--0.15 mm wide at the base. Upright shoots gradually diminishing and branched successively 3 times, $3--12 \mathrm{~cm}$ from base to form complex treelike habit. Lateral branchlets spreading-ascending, drooping at tips, 0.2--0.4 $\mathrm{mm}$ wide, lycophylls needlelike, recurved basally, upcurved apically, 2--2.5 mm long, 0.1--0.2 mm wide at the base, lycophylls and stems sometimes hairy near strobili.Strobili nodding at $60--80^{\circ}$ to subtending vegetative branch, 0.4--0.8 mm long, 1.5--2 mm wide. Sporophylls trowel-shaped, 1.5--2 mm long, $0.7-0.8 \mathrm{~mm}$ wide, margins fringed, teeth to $0.2 \mathrm{~mm}$, mostly branched. Sporangia nearly globose. Spore surface rugulate; sides convex at equator. 

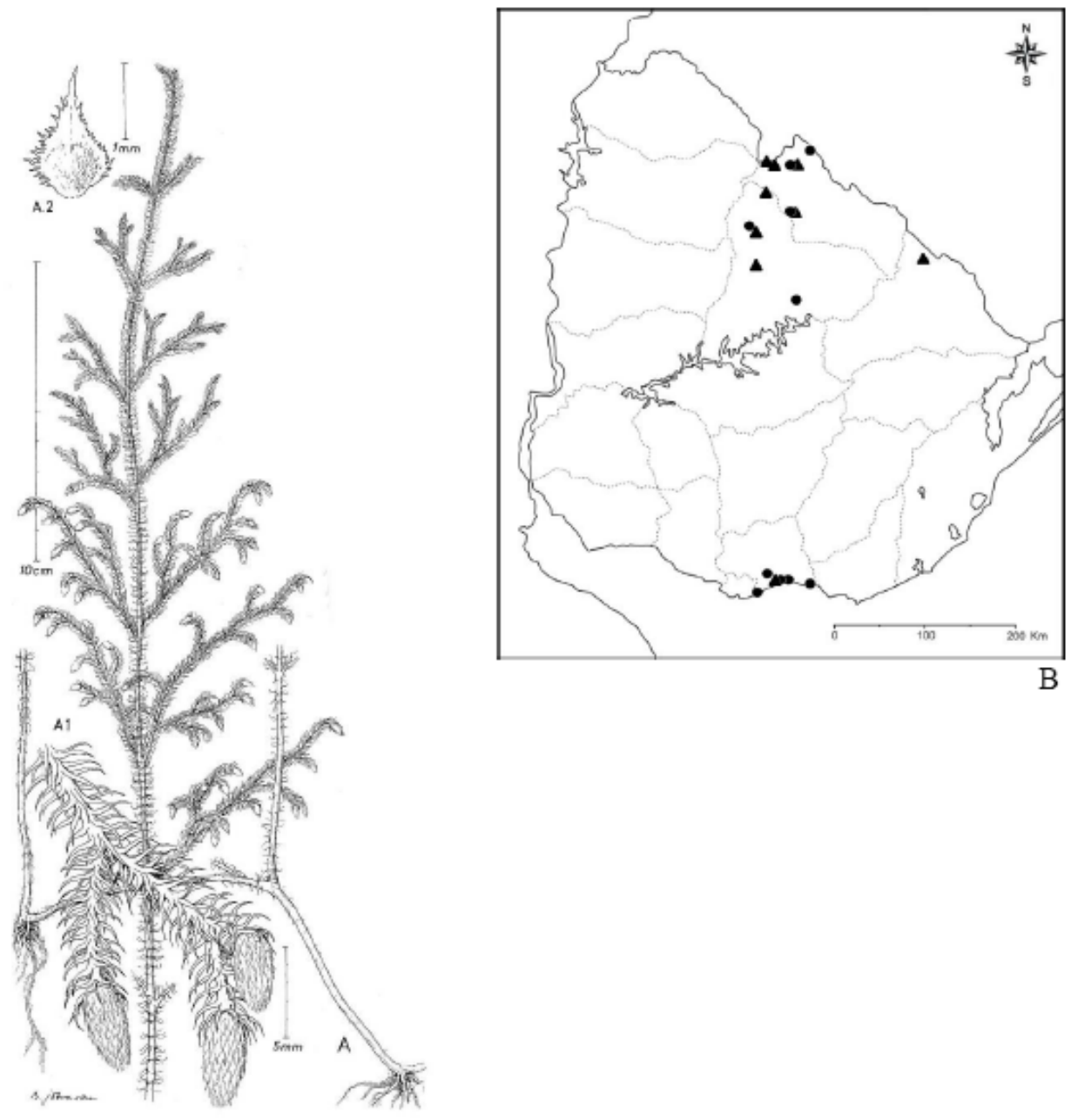

Figure 6. A. Palhinhaea cernua habit. A1 segment with strobili. A2 sporophyll. B. Distribution of Palhinhaea cernua (triangles) and Pseudolycopodiella meridionalis (circles).

Distribution and habitat: almost worldwide, Palhinhaea cernua is probably one of the world's most abundant club-moss. In Uruguay is found in wet depressions and road banks of sandy soils or sedimentary rocks; 0--100 m. The species overwinters as buried stem tips, the rest of the plant dying.

Selected Material:URUGUAY.Canelones: Atlántida, Parque de los Pinos, 28-IX-1952, F.C. MüllerMelchers. s.n. (MNHN 14597); Atlántida, Parque de los Pinos, II-1953, F.C. Müller-Melchers. s.n. (MNHN 14596).Cerro Largo: Sierra Aceguá, I-1926, Herter s.n.; Osten 18601 (MNHN 1460).Rivera: 1886, Otero s.n. (MNHN 4158); Tranqueras, 7-V-1945, Legrand 3997 (MNHN 1459); Subida de Pena, Ruta 30, km 111,5, en suelo húmedo arenoso, 11-IV-1984, Bayce, Berrutti, Brescia, Marchesi s.n.(MVFA 17282); Route 30, $3 \mathrm{~km} \mathrm{~W}$ of arroyo Rubio Chico, $31^{\circ} 08^{\prime} 38^{\prime \prime} \mathrm{S}, 55^{\circ} 54^{\prime}$ ' 3.9' W, abundant in sedimentary rocks, 26-X-2003, Bonifacino \& Sytsma 863 (MVFA); Ruta 5, 4 kms al sur del empalme con Ruta 27, Cerro Chato, cornisa de arenisca muy húmedo y sombreado, 3057'59.3' S; 55³4'33.7'’ W; 14-XII-2005, Brussa, C., Grela, I. s.n. (MVJB 24586); Ruta 5, 4 kms al sur del empalme con Ruta 27, Cerro Chato, cornisa de arenisca muy húmedo y sombreado, 3057'59.3' ' S; 55³4'33.7'’ W; 14-XII-2005, Brussa, C., Grela, I. s.n. (MVJB 24591); Ruta 5, 4 kms al sur del empalme con Ruta 27, cornisa Cerro Chato, arbolado, paredones de arenisca semisombra, 32 $38^{\prime} 59.5^{\prime}$ ' S; 55 27'16.2' W, 28-X-2006, Brussa, C., Grela, I. s.n. (MVJB 25457); Arroyo

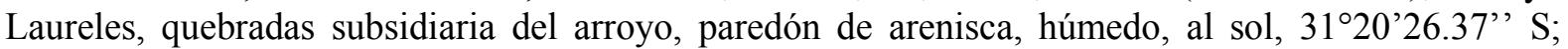
55'53'34.28', W, 9-XI-2006, Brussa, C., Grela, I. s.n. (MVJB 25083); La Fortaleza, cornisas de arenisca al sol, $31^{\circ} 29^{\prime} 00.13^{\prime \prime}$ S; 55³8'57.82' ' W, 18-III-2012, Brussa, C., Escudero, R. s.n. (MVJB

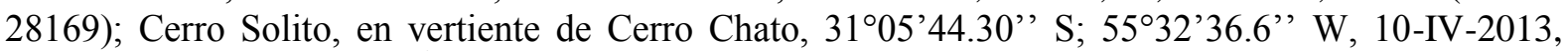
Brussa, C., Escudero, R., Álvarez, M. s.n. (MVJB 28544). Tacuarembó: Gruta de los Cuervos, sf., Chebataroff 4158 (MVJB); Gruta de los helechos, lugar húmedo próximo a la cañada y a pleno sol, 19-VIII-1984, Brussa, C., Gago, J., Scarlatto, G. s.n. (MVJB); Establecimiento La Sierra, bosque de quebrada y campos aledaños, $32^{\circ} 03$ '24.10”' S; 55 54'44.5' 'W, 1-IV-2012, Brussa, C., Escudero, R. s.n. (MVJB 28146). 
5. Phlegmariurus Holub, Preslia, 36 (1): 17,21. 1964. Type:-Phlegmariurus phlegmaria (L.) Holub (= Lycopodium phlegmaria $\mathrm{L}$.).

Plants erect to pendulous, not gemmiferous.Stems isotomously branched throughout, without elongate, indeterminate main stems, but sometimes heteroblasticwith creeping orsubterranean shoots, from which aerial shoots arise, roots usually forming one basal tuft,

sporophylls and vegetative lycophylls alike, or the sporophylls, if smaller, green and persisting after spore dispersal, notsubpeltate and ephemeral; sporangia axillary, not attached to sporophyll, sporangium epidermis cells with sinuate, lignified side walls. Spores foveolate-fossulate with equator line convex between laesurae and with bluntlyangular corners, proximal faces smooth, unornamented, plane. $\mathrm{x}=$ ca. $132,136,138,170$.

5a. Phlegmariurus reflexus (Lam.) B. Øllg. var. minus(Spring) B. Øllg., Rodriguésia 63: 481. 2012.Lycopodium reflexum Lam. var. minus Spring. In Nouv. Mém. Acad. Roy. Sci. Bruxelles 15: 26. 1842.Urostachys reflexus (Lam.) Herter var. minor(Spring) Herter ex Nessel. In Arch. Bot. Sao Paulo 1(4): 393. 1927. Huperzia reflexa (Lam.) Trevis. var. minor (Spring) B. Øllg. In Harling et L. Andersson, Fl. Ecuador 33: 26. 1988.Type:- (Syntipes) Brazil: Pr. Rio de Janeiro,Gaudichaud s.n. (P); Brazil, Rio de Janeiro Langsdorff s.n.; (M, Herb. Mart.), Brazil: Serra dos Orgaos, fr. Majo, Guillemin s.n.(P), Brazil: In sylvis prov. Paraenis Martius s.n.(M), Brazil: in prov. Minarum Claussen s.n. (P).

Lycopodium brutum Herter. In Bot. Jahrb. Syst. 43(Beibl. 98): 47. 1909.Urostachys brutus (Herter) Herter. In Repert. Spec. Nov. Regni Veg 19(11-13): 162. 1923.Urostachys reflexus (Lam.) Herter var. brutus (Herter) Herter ex Nessel. In Bärlappgewächse 116. 1939. Type: — TRINIDAD,Hooker ded. 1845 (holotype P!).

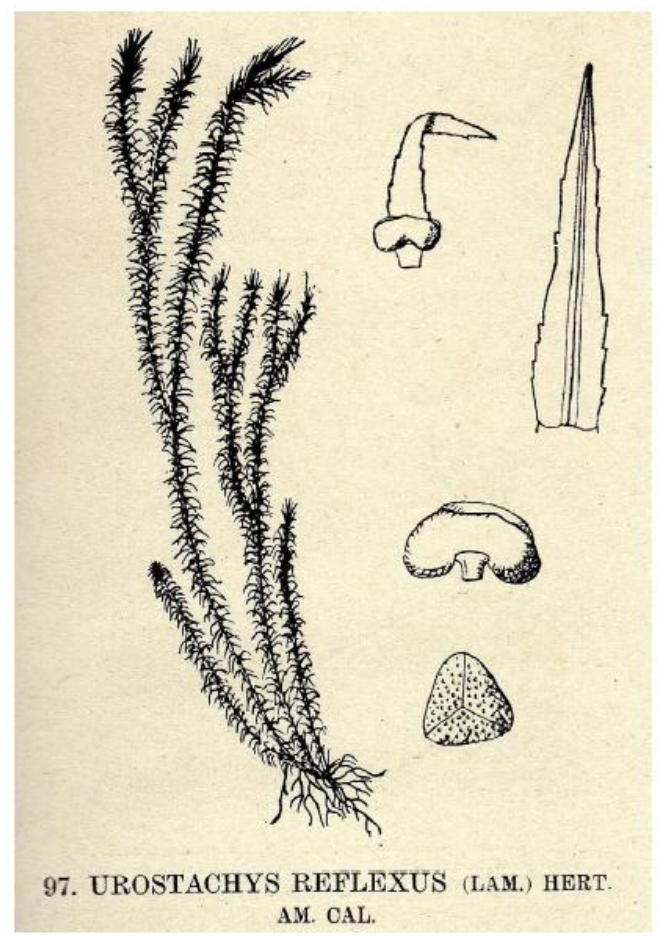

Figure 7. Phlegmariurus reflexus var. minus habit (modified from Herter, 1939).

Plants terrestrial, or occasionally epiphytic, erect or ascending from a decumbent base, $8-30 \mathrm{~cm} \mathrm{long}$, sparsely branched, or up to 5 times dichotomous, the divisions usuallyparallel or slightly diverging; stems pale greenish to stramineouswhen dried, shoots sporangiate throughout from $2-10 \mathrm{~cm}$ above the ground, orin seasonally produced zones; lycophylls uniform in size and shape throughout in more or lessregular, often oblique, alternating whorls of 6 or 7 (-8) leaves, forming 12-14 (-16) ranks,crowded to somewhat distant, the distance between successive leaf whorls $1-2 \mathrm{~mm}$; lycophylls spreading or recurved to reflexed, subulate, herbaceous to subcoriaceous, $4.5-8 \mathrm{~mm}$ long, $0.5-1 \mathrm{~mm}$ broad just above the base, with slightly narrowed junction to the stem, evenlytapering, with denticulate to stifflyciliolate margins, flat, or with a low to prominent anddecurrent vein below; sporangiareniform, 0.8-1.5 mm broad.

Distribution and habitat: from Mexico, Mesoamerica, Antilles to South America: Colombia, 
Venezuela, Guyana, French Guyana, Ecuador, Peru, Bolivia, Brazil, Paraguay, Argentina and Uruguay. The species is pioneer onmoist open or shaded banks, in montane forests, rarely epiphytic on tree trunks, or in bogs, sometimes in sunny places, from 300 to $3000 \mathrm{~m}$ asl.

Note: Phlegmariurus reflexus was mentioned for Uruguay by Herter (1939), without herbarium specimens of reference. Here the presence of $P$. reflexus for the Uruguayan flora is confirmed with the variety $P$. reflexus var. minus. "Recently the species was found at the south of the country, in Departamento Maldonado by Berazategui et al. (com. pers.) and also in Departamento Rivera at cerro Miriñaque".

Selected Material:URUGUAY. Rivera.Barranca de arenisca, uliginosa, próxima a ruta nacional $\mathrm{n}^{\circ}$, $\mathrm{Km}$ 491, próximo al $\mathrm{A}^{\circ}$ Curticeiras. En paredón uliginoso, arenisca, con exposición este, bajo matorral de Escallonia, semisombrío,3058'33.22"S y 55³4'20.90"O, 3-II-2016, Brussa C., Brussa, P.\&Álvarez, M. s.n. (MVJB 29545).

6. Pseudolycopodiella Holub, Folia Geobot. Phytotax. 18: 441. 1983. Type:-Pseudolycopodiella caroliniana (L.) Holub (= Lycopodium carolinianum L.).

Plants creeping on wet substrates. Roots emerging immediately on underside of stems. Horizontal stems on substrate surface, short-creeping. Upright shoots not branched, forming sparsely leafy peduncles scattered along horizontal stem, nearly naked, 9--11 mm diam. Lycophylls of horizontal stems not in distinct ranks, not imbricate, dimorphic, margins entire; lateral lycophylls narrowly linear, nearly subulate, median lycophylls $1 / 2--2 / 3$ shorter than lateral lycophylls, ascending. Gemmiferous branchlets and gemmae absent. Strobili solitary, not conspicuously differentiated from peduncle, tip blunt; peduncle nearly naked with scattered minute lycophylls, 0.9--3 mm diam.; sporophylls much shorter than peduncle leaves. Sporangia reniform. Spores rugulate, sides at equator convex, angles acute. Gametophytes photosynthetic, on substrate surface, tuber-shaped and lobed; ring meristem absent. $\mathrm{x}=35$.

Species 12 worldwide, one in the Uruguayan flora.

6a. Pseudolycopodiella meridionalis (Underw. \& Lloyd) Holub, Folia Geobot. Phytotax. 18:

442. 1983. Lycopodium meridionale Underw. \& F. E. Lloyd, Bull. Torr. Bot. Club 33: 121. 1906. Lycopodiella caroliniana (L.) Pichi-Sermolli var. meridionalis (Underw. \& F. E. Lloyd) B. Øllg. \& Windisch, Bradea 5(1): 27. 1987. Type:-PUERTO RICO. "Luquillo Mountains, dry savannahs", P. Wilson 94 (holotype NY!).

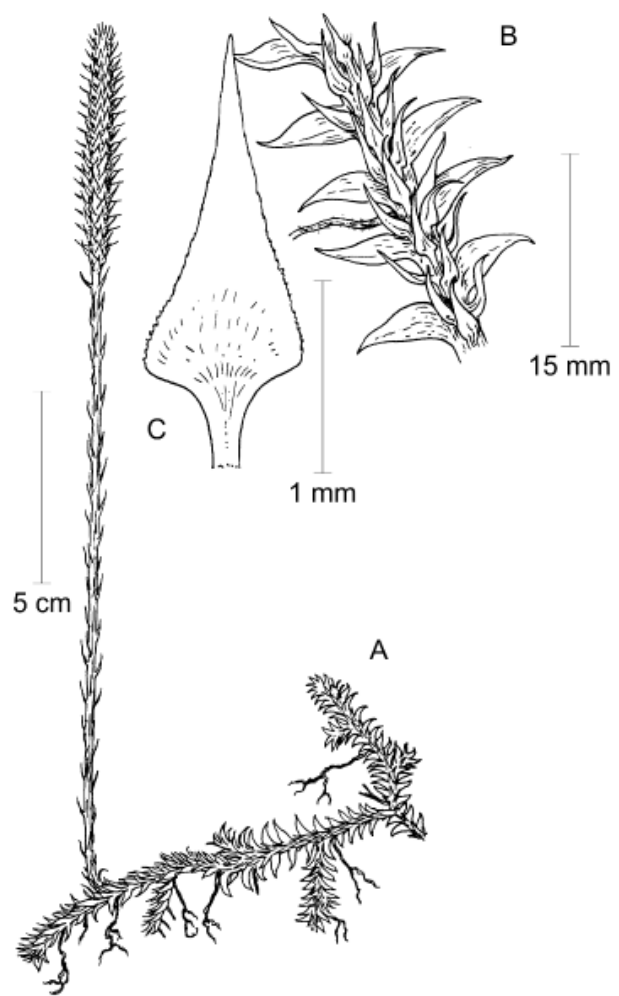

Figure 8. Pseudolycopodiella meridionalis A. habit. B. segment of horizontal stem. C. sporophyll. 
Terrestrial, with horizontal stems creeping and firmly rooted throughout, bearing one to few, dorsally arising, stiffly erect, simple, strobilus-bearing branches (peduncles). Creeping shoots up to ca $30 \mathrm{~cm}$ long, sparsely and unequally branched, anisophyllous, with long and broad lateral lycophylls, and usually shorter and narrower dorsal lycophylls; lateral lycophylls $3-5$ (-7) $\mathrm{mm}$ long, (1-) $1.5-2.5$ (-3) $\mathrm{mm}$ broad at the base, varying from broadly triangular-ovate to lanceolate, obliquely spreading to falcately recurved, usually with a strongly curved, underlying acroscopic margin, and short to long decurrent basiscopic margins, tapering into an acute to long pointed apex, flat, with smooth margins. Dorsal lycophylls arranged in (1-) 2-4 longitudinal ranks, broadly lanceolate to subulate or rarely triangular-ovate, diverging to appressed,straight to upward curved, (1.5-) 3-4 (-5) $\mathrm{mm}$ long, 1$1.3(-2) \mathrm{mm}$ broad at the base. Erect branches at least up to $30 \mathrm{~cm}$ tall incl. the strobilus, terete, bearing small, 3-5 mm long, acicular lycophylls in remote, alternating, spirals or irregular whorls of $4-5$, these up to $8 \mathrm{~mm}$ apart. Strobili up to at least $13 \mathrm{~cm}$ long, $3-5 \mathrm{~mm}$ thick with appressed sporophylls. Sporophylls borne in alternating whorls of 4 or 5 (-6), forming $8-10(-12)$ longitudinal ranks, subpeltate, with a thin, median, basiscopic, decurrent wing; the exterior face rhombic or ovate-acuminate or ovate-cuspidate to triangular-lanceolate, $3.5-6 \mathrm{~mm}$ long, $(1-)$ 1.52 (-2.5) $\mathrm{mm}$ broad, with subscarious, entire to erose-denticulate, minutely fimbriate-denticulate margins. Sporangia reniform, isovalvate, borne on the sporophyll stalk, ca. $1.5-2 \mathrm{~mm}$ broad.

Distribution and habitat: widely distributed in tropical America. In Uruguay is found in acid wetlands near Atlantic coast.

Notes: The "Caroliniana group" is in need of a detailed worldwide revision. The distinctness of the present taxon from the type species (from Temperate North America) has been doubted (e. g. Proctor 1977, p. 32-33), but the South American material differs from the type species by the generally larger size and by the minutely and usually densely denticulate sporophyll margins.

Selected Material:URUGUAY.Canelones: Atlántida, suelo arenoso, húmedo, 0.2-4 M.s.m., 20-IV1935, Herter 1776 (MNHN 1444); La Floresta, I-1937, Lombardo, A. 1970 (MVJB);Playa Santa Rosa, 6-III-1942, Legrand 3076 (MNHN 1446); Bañados de Pando, I-1944, Lombardo, A. 4993 (MVJB); La Floresta, 15-XII-1993, Lombardo, A. 1259 (MVJB 12488); En bañado ácido, junto a la playa del balneario Santa Ana, 3-IV-1999, Bonifacino \& Beyhaut s.n. (MFVA 28857); Atlántida,5IV- 1920, Herter 193 (SI). Montevideo:Carrasco, junto con el alopecuroides, XII-1881, Arechavaleta s.n. (MNHN 2056); Carrasco, 1881, Spegazzini s.n. (SI).Tacuarembó: Rincón de Zamora, nacientes de Arroyo Clara, pared barrancosa muy húmeda, sobre cañada, 25-II-1978, Ferrés s.n. (MVFA 15073); Gruta de los Cuervos, 9-III-1966, Rosengurtt, Del Puerto \& Marchesi s.n. (MVFA 10081).Rivera: 1886, Otero s.n. (MNHN 4226); Establecimiento Delio Vetorello. Campo natural uliginoso, 31 ${ }^{\circ} 02^{\prime} 55.75^{\prime}$ " S; 55 37'24.21' ' W, 6-XI-2011, Brussa, C. \& Álvarez, M. s.n. (MVJB 28164); La Fortaleza, Cornisas de arenisca al sol, en vertientes húmedas, 31 ${ }^{\circ} 29^{\prime} 00.13^{\prime}$ ' S; 55 38'57.82' ' W, 18-III-2012, Brussa, C. \& Escudero, R. s.n. (MVJB 28168); Cerro Chato Dorado, Ruta 27, en arenisca húmeda próximo a zona de vertiente. No inundado, 31 04 '05.36' 'S; 55²7'47.33’'W, 12-II-2015, Brussa, C. s.n. (MVJB 29378).

\section{ACKNOWLEDGEMENTS}

We are grateful to the Editor and the anonymous Reviewers for their valuable suggestions on the manuscript, to Irina Aldabe and Martin Abreu for their gracious help during field expeditions, and to Heraldo Mussolini for drawing some the illustrations of this manuscript. The authors want to thank to Pablo Berazategui and Cambium forestall that called our attention to populations of Phlegmariurus reflexus, and also to COFUSA for allow us to collect in Reserva Batoví.

\section{REFERENCES}

Arana MD, Morrone JJ, Ganem MA, Luna ML, Ramos Giacosa JP, Giudice G. 2012. Diversidad y análisis panbiogeográfico de las licofitas (Embryopsida: Lycopodiidae) del Parque Nacional Calilegua, Jujuy, Argentina. Iheringia (Série Botanica) 67: 177-188.

Arana MD, Øllgaard B. 2012. Revisión de las Lycopodiaceae (Embryopsida, Lycopodiidae) de Argentina y Uruguay. Darwiniana 50(2): 266-295.

Bridson D, Forman L. 1998. The herbarium Handbook. London, The Royal Botanic Garden Kew.

Bruce JG. 1976. Development and distribution of mucilage canals in Lycopodium. American

Fern Journal, 63: 481-491.

Brummit RK, Powell CE. 1992. Author of plants names. London, The Royal Botanic Garden Kew.

International Journal of Advanced Research in Botany (IJARB)

Page | 37 
Brussa CA, Grela I. 2005. Revisión taxonómica de Pteridophyta en Uruguay. Boletín de la Sociedad Argentina de Botánica (Suplemento) 40: 193.

Ching R-C. 1981. The taxonomy of Chinese Lycopodiaceae (sen. lat.) I, II. Acta Botanica Yunnanica 3: 1-9, 291-305.

Ching R-C. 1982. The taxonomy of Chinese Lycopodiaceae (sen. lat.) III, VI. Acta Botanica Yunnanica 4: 119$128,213-226$.

de la Sota ER.. 1977. Pteridophyta, en A. L. Cabrera (ed.), Florade la Provincia de Jujuy. Colección Científica del InstitutoNacional de Tecnología Agropecuaria 13(2): XIV, 275.

Doyle JA. 1998. Phylogeny of vascular plants. Annual Review of Ecology, Evolution, and Systematics 29: 567599.

Gonzalez HA, Brussa CA, Arana MD. 2015.Diphasiastrum thyoides (Lycopodiaceae), nuevo registro para la flora uruguaya. Boletín de la Sociedad Argentina de Botánica50 (2): 255-259.

Herter, G. 1939. Flora ilustrada del Uruguay I. Estudios Botánicos en la Región Uruguaya XIV. Montevideo. El Autor. $256+[13] \mathrm{p}$.

Holub J. 1964. Lycopodiella, novy rod radu Lycopodiales. Preslia 36: 16-22.

Holub J. 1975. Diphasiastrum, a new genus in Lycopodiaceae. Preslia47: 97-110.

Holub J. 1983. Validation of generic names in Lycopodiaceae: with a description of a new genus Pseudolycopodiella. Folia Geobotanica \& Phytotaxonomica18: 439-442.

Holub J. 1985. Transfer of Lycopodium species to Huperzia with a note on generic classification in Huperziaceae. Folia Geobotanica \& Phytotaxonomica20: 67-80.

Holub J. 1991. Some taxonomic changes within Lycopodiales. Folia Geobotanica \& Phytotaxonomica 26: 8194.

Ji S, Huo K, Wang J, Pan S. 2008. A molecular phylogenetic study of Huperziaceae based on chloroplast rbcL and psbA-trnH sequences. Journal of Systematics and Evolution (Acta Phytotaxonomica Sinica) 46 (2): 213-219.

Kenrick P, Crane PR. 1997. The origin and early diversification of land plants: A cladistic study. Washington D.C.: Smithsonian Institution Press.

Kunze G. 1843. Phylloglossum genus novum ex ordine novo. Botanische Zeitung (Berlin) 1:

721-723.

Legrand CMDE, Lombardo A. 1958. Flora del Uruguay I. Pteridophyta, Montevideo, Museo Nacional de Historia Natural. pp 1-67.

Morrone JJ. 2014. Biogeographical regionalisation of the Neotropical region. Zootaxa 3782: 1-110.

Øllgaard B.1975. Studies in the Lycopodiaceae I. Observations of the structure of the sporangium wall. American Fern Journal, 65, 19-27. doi: 10.2307/1546590

Øllgaard B.1979. Studies in the Lycopodiaceae II. The branching patterns and infrageneric groups of Lycopodium sensu lato. American Fern Journal, 69, 49-61. doi: 10.2307/1546896

Øllgaard B. 1983. Lycopodiaceae, en R. G. Stolze (ed.), Ferns and fern allies of Guatemala, part III. Fieldiana Botanica 12: 20-44.

Øllgaard B. 1987. A revised classification of the Lycopodiaceae s. lat. Opera Botanica 92: 153-178.

Øllgaard B. 1989. Index of the Lycopodiaceae. Biologiske skrifter. Royal Danish Academy of Sciences and Letters.

Øllgaard B. 1990. Lycopodiaceae, en K. Kubitzki (ed.), The Families and Genera of Vascular Plants I, pp 31-39. Berlin \& Heidelberg: Springer-Verlag.

Øllgaard B. 1992. Neotropical Lycopodiaceae, an overview. Annals of the Missouri Botanical Garden 79: 687717.

Øllgaard B. 1994. Lycopodiaceae, en R. M. Tryon \& R. G. Stolze (eds.), Pteridophyta of Peru, Parte VI. Fieldiana Botanica 34: 16-66.

Øllgaard B. 2004. Novelties in Neotropical Lycopodiaceae. Nordic Journal of Botany 23: 31-47.

Øllgaard B. 2012a. Nomenclatural changes in Brazilian Lycopodiaceae. Rodriguésia 63: 479-482.

Øllgaard B. 2012b. New combinations in Neotropical Lycopodiaceae. Phytotaxa 57: 10-22.

Øllgaard B. 2015. Six new species and some nomenclatural changes in neotropical Lycopodiaceae. Nordic Journal of Botany 33(2): 186-196.

Panario D, Gutiérrez O, Sánchez Bettucci L, Peel E, Oyhantçabal P, Rabassa J. 2014. Ancient landscapes of Uruguay. In: Rabassa J, Clifford O. (eds.) Gondwana Landscapes of Southern South America. Dordrecht, Springer Science \& Business Media. p. 161-200. 
PPG I (The Pteridophyte Phylogeny Group)2016. A community-derived classification for extant lycophytes and ferns. J. Syst. Evol. 54 (6): 563-603.

Proctor GR. 1977. Flora of the Lesser Antilles. 2. Pteridophyta. Jamaica Plains, Mass.: Arnold Arboretum.

Pryer KM, Schneider H, MagallónS. 2004. The radiation of vascular plants, In J. Cracraft \& M. Donoghue (eds.), Assembling the Tree of Life, pp 138-153. New York: Oxford

University Press.

Ramos Giacosa JP, Morbelli MA, Giudice, GE, Gorrer DA. 2016. Spore morphology and wall ultrastructure of Lycopodiaceae from northwest Argentina. Review of Palaeobotany and Palynology 225: 84-94.

Rolleri CH. 1979. Análisis morfológico y revisión sistemática de las especies andinopatagónicas del género Lycopodium L. (Lycopodiaceae- Pteridophyta). Physis Sección C 38: 39-62.

Rolleri CH. 1981. Sinopsis de las especies de Lycopodium L.(Lycopodiaceae-Pteridophyta) de la sección CrassistachysHerter. Revista del Museo de La Plata, Sección Botánica13:61-114.

Rolleri CH. 2008. Lycopodiaceae. In ZuloagaFO, MorroneO,BelgranoMJ, Marticorena C, MarchesiE. (eds.)Catálogo de las Plantas Vasculares del Cono Sur(Argentina,Sur de Brasil, Chile, Paraguay y Uruguay). Monographs inSystematic Botany from the Missouri Botanical Garden 107:84-96.

Tryon RM., Tryon AF. 1982. Ferns and allied plants, with special reference to Tropical America. New York: Springer-Verlag.

Wagner WH Jr., Beitel JM. 1992. Generic classification of modern North American Lycopodiaceae. Annals of the Missouri Botanical Garden 79: 676-686.

Wikstrom N., KenrickP. 2000. Phylogeny of epiphytic Huperzia (Lycopodiaceae): paleotropical and neotropical clades corroborated by plastid rbcL sequences. Nordic Journal of Botany 20: 165- 171.

Wikstrom N., Kenrick P. 2001. Evolution of Lycopodiaceae (Lycopsida): Estimating divergence times from rbcL sequences by use of nonparametric rate smoothing. Molecular

Phylogenetics and Evolution 19: 177- 186.

Wilce JH. 1972. Lycopod spores, 1. General spore patterns and the generic segregates of Lycopodium. American Fern Journal, 52, 65-79. doi: 10.2307/1546437

Books

Smith GM. 1938. Cryptogamic botany. Vol. II Bryophytes and Pteridophytes. 2nd. edn. New York, McGrawHill Book Company.

Chapters in books

Schupp EW, Feener DH. 1991. Phylogeny, lifeform, and habitat dependence of ant-defended plants in a Panamanian forest. In: Huxley CR, Cutler DC. (eds.) Ant-plant interactions. Oxford, Oxford University Press. p. 175-197.

Citation: M. D. Arana et al. , " A Revision of Lycopodiaceae from Uruguay ", International Journal of Advanced Research in Botany, vol. 3, no. 4, p. 24-39, 2017. http://dx.doi.org/10.20431/2455-4316.0304004

Copyright: (C) 2017 Authors. This is an open-access article distributed under the terms of the Creative Commons Attribution License, which permits unrestricted use, distribution, and reproduction in any medium, provided the original author and source are credited. 